\section{FRI0122 PREDICTING FACTORS FOR DISAPPEARANCE OF ANTI-MUTATED CITRULLINATED VIMENTIN ANTIBODIES IN SERA FROM PATIENTS WITH RHEUMATOID ARTHRITIS}

N. Ishigooka $^{1}$, T. Fujii ${ }^{1,2}$, S. Kondo-Ishikawa ${ }^{1}$, M. Hashimoto $^{3}$, M. Furu ${ }^{3}$, M. Tanaka ${ }^{3}$, H. Ito ${ }^{4}$, R. Nakashima ${ }^{1}$, K. Murakami ${ }^{1}$, Y. Imura ${ }^{1}$, H. Yoshifuji ${ }^{1}$, K. Ohmura ${ }^{1}$, T. Mimori ${ }^{1} .{ }^{1}$ Department of Rheumatology and Clinical Immunology, Kyoto University Graduate School of medicine, Kyoto; ${ }^{2}$ Department of Rheumatology and Clinical Immunology, Wakayama Medical University, Wakayama; ${ }^{3}$ Department of the Control for Rheumatic Diseases; ${ }^{4}$ Department of Orthopaedic Surgery, Kyoto University Graduate School of medicine, Kyoto, Japan

Background: Mutated citrullinated vimentin (MCV) is one of the important targets of anti-citrullinated protein/peptide antibodies (ACPA) and is found in synovial fluid in patients with rheumatoid arthritis (RA). Serum anti-MCV antibody (antiMCV) titer may be better correlated with RA disease activity and radiographic progression than anti-cyclic citrullinated peptide antibody (anti-CCP) titer.

Objectives: In the present study, we tried to determine the predicting factor of anti-MCV disappearance in sera from RA patients.

Methods: Both anti-MCV (ORGENTEC Diagnostika, Germany) and anti-CCP (MESACUPTM -2 test CCP, MBL, Japan) in sera from 280 RA patients who met 2010 ACR/EULAR classification criteria in Kyoto University RA Management Alliance (KURAMA) cohort 2013 and 2014 were measured by ELISA. Then, we determined retrospectively the predicting factors of anti-MCV disappearance using multivariate logistic analysis.

Results: In 2013 cohort, anti-MCV and anti-CCP positivities were 64.6 and $84.6 \%$, respectively. The majority (97.8\%) of anti-MCV-positive patients was also anti-CCP-positive and there was significant correlation between anti-MCV and anti-CCP titers $(r=0.63, p<0.001)$. In 2013 baseline, there was no difference in patients' age, gender and disease duration between anti-MCV-positive $(n=181$, $64.6 \%)$ and -negative $(n=99,35.4 \%)$ groups. DAS28, however, was higher in anti-MCV-positive group than in -negative group (3.08 \pm 1.22 vs. $2.68 \pm 1.07$, $p=0.011)$, while anti-CCP-positive $(n=237,84.6 \%)$ and -negative $(n=43,15.4 \%)$ groups had no significant difference of DAS28. Of note, whereas anti-CCP positivity rate did not change during 2013 and 2014, anti-MCV changed to positive and to negative were recognized in $20(=7.2 \%)$ and $41 \quad(=14.6 \%$, disappeared group) patients. So we next compared anti-MCV disappeared and sustained-positive groups $(n=140,50.0 \%)$. There was no difference in patients' age, gender, disease duration and DAS28 in 2013. While decrease of DAS28 from 2013 to 2014 (= $\triangle$ DAS28) in disappeared group was more apparent than that in sustained-positive group $(-0.58 \pm 1.1$ vs. $+0.02 \pm 0.34, p=0.028)$. Methotorexate monotherapy was rarer in disappeared group than in sustained-positive group ( $26.5 \%$ vs. $53.8 \%, p=0.015)$, while continuous use of biological disease modifying antirheumatic drug (bDMARD) was more frequent in disappeared than sustainedpositive group $(64.7 \%$ vs. $25.2 \%, p<0.0001)$. Also serum levels of $K L-6$, a serum marker of interstitial lung disease, were lower in disappeared than in sustainedpositive group ( $255 \pm 146$ vs. $315 \pm 183, p=0.006)$. To clear the most effective factor in anti-MCV disappearance, we choose variables including anti-MCV titers in baseline, KL-6 levels, $\triangle \mathrm{DAS} 28$ and bDMARD use, and performed multivariable analysis. Analysis showed that anti-MCV titers and bDMARD use, especially TNF inhibitor (Odds Ratio $=7.2, p<0.001$ ) were observed as the predicting factors of anti-MCV disappearance. On the other hand, no predicting factor for newly anti-MCV appearance was recognized in our cohort.

Conclusions: Anti-MCV, but not anti-CCP, can be disappeared in a year by continuous bDMARD use regardless of disease activity.

Disclosure of Interest: None declared

DOI: 10.1136/annrheumdis-2017-eular.1589

\section{FRI0123 DOES THE BODY MASS INDEX HAVE ANY INFLUENCE IN THE} CHARACTERISTICS OF EARLY ARTHRITIS PATIENTS?

P. Moreno Fresneda, L. Martínez-Quintanilla, A.M. Ortiz, E. Tomero, R. García Vicuña, I. González Álvaro. Rheumatology Deparment, Hospital Universitario de la Princesa, Madrid (Madrid), Spain

Background: Obesity has been proposed as a risk factor to develop rheumatoid arthritis (RA) and it has been associated with a worse response to several disease modifying anti-rheumatic drugs (DMARDs).

Objectives: To study the differences in baseline characteristics according to the body mass index (BMI) of patients in the PEARL (Princesa Early Arthritis Register Longitudinal) study.

Methods: A total of 432 patients $(69.1 \%$ female) of the PEARL cohort were included for this study. The register protocol comprises the collection of sociodemographic, disease-related and treatment data in five visits (baseline, 6, 12, 24 and 60 months). The local ethics and clinical research committee approved the protocol and all patients sign an informed consent prior to their inclusion. For this study it was analyzed the baseline visit data from the 304 (70.37\%) patients that met ACR 1987 criteria for RA after 2 years of follow-up, as well as those considered undifferentiated arthritis (UA) since other diagnoses were excluded. The WHO definition for low, normal weight, overweight and obesity (BMI $<18.5,18.5-25,25-30$ or $>30 \mathrm{~kg} / \mathrm{m}^{2}$ respectively) was applied. ACPA (anticitrullinated peptide antibodies) were assessed by enzyme immunoassay (CCP2 Eurodiagnostica). HLA-DRB1 genotype was determined in 219 patients using specific HLADRB1 typing kits (Dynal RELI SSO). The presence of shared epitope (SE) was determined based on this genotyping. The statistical analysis was performed by using Stata 12.1. Chi-Square and Kruskal-Wallis tests were used for the bivariate analysis. A multivariate logistic regression was performed to determine which factors may be related to ACPA positivity, including BMI, age, sex, smoking habit, number of SE alleles and study level as independent variables.

Results: Patients were 54.9 years old [44.2-67.5] (median [p25-p75]); disease duration was 5.3 months [3-8.4]. Table 1 shows the main variables significantly associated to BMI. In addition, we observed less ACPA positivity with increasing BMI $(57 \%$ low weight vs. $43 \%$ in obese [ $p=0.08])$, as well as a lower frequency of SE in patients with a higher BMI. The multivariate analysis confirmed that being smoker (ever or current) and carrying SE alleles is associated with the presence of ACPA. Adjusted by these variables, overweight and obesity were associated with lower probability of suffering an ACPA positive disease (OR $0.49, p=0.027$ and OR $0.39, \mathrm{p}=0.019$ respectively).

Table 1. Variables significantly different according to BMI

\begin{tabular}{lcccccc}
\hline BMI & $\begin{array}{c}\text { Age } \\
\text { (years) }\end{array}$ & $\begin{array}{c}\text { Sex } \\
(\mathrm{W} / \mathrm{M})\end{array}$ & $\begin{array}{c}\text { Level of studies } \\
(\mathrm{N} / \mathrm{P} / \mathrm{Se} / \mathrm{U} ; \%)\end{array}$ & HAQ & VAS pain & TJC28 \\
\hline
\end{tabular}

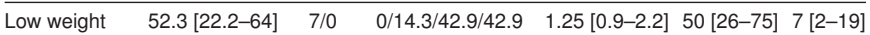

Normal weight $50[38.6-64] \quad 145 / 24 \quad 1.2 / 21.4 / 35.1 / 42.3 \quad 0.87[0.4-1.4] 41[20-61] \quad 3[0-7]$

$\begin{array}{lllllll}\text { Overweight } & 57.9[47-69.6] & 120 / 45 & 8.5 / 35.4 / 32.9 / 23.2 & 0.87[0.5-1.6] & 49[20-62] & 3[0-9]\end{array}$

$\begin{array}{lllllll}\text { Obesity } & 59[50.7-69.8] & 68 / 23 & 12 / 38.5 / 26.5 / 22.9 & 1.3[0.7-1.9] & 50[36-65] & 5[2-12]\end{array}$ $\begin{array}{llcccc}\mathrm{p} \leq 0.001 & \mathrm{p}=0.01 & \mathrm{p} \leq 0.001 & \mathrm{p}=0.0018 & \mathrm{p}=0.031 & \mathrm{p}=0.047\end{array}$

*HAQ: Health Assessment Questionnaire; VAS: visual analogic scale (mm); TJC28: tender joints count (28 joints); W: women; M: men; N: no studies; P: primary studies; Se: secondary studies; $\mathrm{U}$ : universitary studies.

Conclusions: In our early arthritis register, patients with a higher BMI have predominantly ACPA negative disease, a more intense perception of pain and higher disability. These findings should be validated in other populations.

Disclosure of Interest: None declared

DOI: 10.1136/annrheumdis-2017-eular.4458

\section{FRI0124 TEMPORARY INTERRUPTIONS OF STUDY DRUG DURING THE BARICITINIB PHASE 3 RHEUMATOID ARTHRITIS PROGRAM}

P. Emery ${ }^{1}$, Y. Tanaka ${ }^{2}$, T.E. Cardillo ${ }^{3}$, D.E. Schlichting ${ }^{3}$, S. Beattie ${ }^{3}$, L. Chen $^{3}$, T.P. Rooney ${ }^{3}$, J.S. Smolen ${ }^{4} .{ }^{1}$ Leeds MSK Biomed/Chapel Allerton Hosp, Leeds, United Kingdom; ${ }^{2}$ University of Occupational \& Environmental Health,

Kitakyushu, Japan; ${ }^{3}$ Eli Lilly and Company, Indianapolis, United States; ${ }^{4}$ Medical University of Vienna, Vienna, Austria

Background: Temporary interruption of RA therapy is common in clinical practice; therefore, rapid clearance and low immunogenicity may be useful DMARD attributes. Baricitinib (bari) is a non-biologic Janus kinase (JAK) 1/JAK2 selective inhibitor with a pharmacokinetic half-life in RA patients of approximately 13 hours. It has demonstrated improved clinical efficacy compared to MTX, adalimumab and placebo (pbo) with a satisfactory safety profile when administered once daily to RA patients in 4 completed Phase 3 studies.

Objectives: These analyses aimed to characterize temporary interruptions of study drug during these studies and explore the kinetics of RA symptoms during and following interruption.

Methods: During bari Phase 3 studies, investigators were required to document temporary interruptions of study drug, including timing, reason and duration, using electronic case report forms. In 2 studies, patients recorded RA symptoms (duration and severity of morning joint stiffness, worst tiredness and worst joint pain) daily for 12 weeks. Post hoc analyses investigated changes in these scores among patients randomized at least 7 days prior to interruption, having an interruption that lasted at least 3 days, and retreated.

Results: Across the 3 pbo-controlled studies, interruptions occurred in a larger proportion of patients with bari than pbo only in the biologic DMARD-inadequate responder (IR) study RA-BEACON. In the 2 active comparator-controlled studies, the lowest rates of interruption were in the bari monotherapy arm of the DMARDnaïve MTX-controlled RA-BEGIN study, and proportions were similar for bari and adalimumab in the MTX-IR study, RA-BEAM (Table 1). Adverse events (predominantly non-serious, mild or moderate infections, most commonly of the respiratory tract) were the most frequent reason for interruption. Few patients interrupted for the reason of abnormal laboratory results. Most interruptions lasted for 2 weeks or less; in RA-BEAM, interruptions appeared shorter in duration for bari than for adalimumab. Diary measures indicated modest symptom increases during interruption compared to the last pre-interruption value, with a return to pre-interruption values or better after resumption of study drug (Table 2).

Conclusions: Consistent with its pharmacologic properties, brief temporary interruptions of bari during Phase 3 studies were associated with minor increases in RA symptoms, which resolved following resumption of therapy. A small molecule with a short half-life may offer advantages over injectable biologic therapies with respect to drug interruption for clinical cause in RA patients.

Disclosure of Interest: P. Emery Consultant for: Pfizer, MSD, Abbvie, BMS, UCB, Roche, Novartis, Samsung, Sandoz, Eli Lilly and Company, Y. Tanaka Grant/research support from: Mitsubishi-Tanabe, Takeda, Daiichi-Sankyo, Chugai, Bristol-Myers, MSD, Astellas, Abbvie, Eisai, Speakers bureau: Abbvie, Chugai, Daiichi-Sankyo, Bristol-Myers, Mitsubishi-Tanabe, Astellas, Takeda, Pfizer, Teijin, 


\begin{tabular}{|c|c|c|c|c|c|c|c|c|c|}
\hline & & & \multicolumn{4}{|c|}{$\begin{array}{l}\text { Study RA-BEAM } \\
\text { (0-240-52, data up to rescue) }\end{array}$} & \multicolumn{3}{|c|}{$\begin{array}{l}\text { Study RA-BUILD } \\
\text { (0-24, data up to rescue) }\end{array}$} \\
\hline & & & $\begin{array}{c}\text { PBO } \\
(N=488)\end{array}$ & $\begin{array}{l}\text { BARl } 4 \mathrm{mg} \\
(\mathrm{N}=487)\end{array}$ & \multicolumn{2}{|c|}{$\begin{array}{c}\text { ADA } \\
(\mathrm{H}=330)\end{array}$} & $\begin{array}{c}\begin{array}{c}P 80 \\
(N=228)\end{array} \\
\text { B }\end{array}$ & \multicolumn{2}{|c|}{$\begin{array}{l}\text { BARI } 2 \mathrm{mg} \text { BARI } 4 \mathrm{mg} \\
(N=229) \quad(H=227)\end{array}$} \\
\hline \multicolumn{3}{|c|}{ Total number of dose interruptons, I } & 67 & 62/103 & \multicolumn{2}{|c|}{$\begin{array}{l}30 \\
146\end{array}$} & 32 & 24 & 40 \\
\hline \multirow{2}{*}{\multicolumn{3}{|c|}{ Patients with $\geq 1$ interruption, $n$ (\% of W) }} & 54 (11.1) & $50(10.3) 75$ (15.4) & \multicolumn{2}{|c|}{$28(8.5) / 40(12.1)$} & $29(12.7)$ & $21(9.2)$ & $34(15.0)$ \\
\hline \multirow{2}{*}{\multicolumn{3}{|c|}{$\begin{array}{l}\text { Number of interrupsions per interrupted patient, mean } \\
\text { Time from first dose to first interruption, mean, days }\end{array}$}} & an 1.2 & \multirow{2}{*}{$\begin{array}{c}1.211 .4 \\
70.6 / 128.9\end{array}$} & \multicolumn{2}{|c|}{ 1.11/1.2 } & 1.1 & \multirow{2}{*}{$\begin{array}{r}1.1 \\
41.0\end{array}$} & 1.2 \\
\hline & & & \begin{tabular}{l|l}
5 & 68.9 \\
\end{tabular} & & & \begin{tabular}{l|l}
112.3 &
\end{tabular} & 53.1 & & 53.6 \\
\hline Duration of individ. & alinteruptions. & mean (SD), days & $\mathrm{s} \quad 11.7(13.2)$ & $11.4(9.4) / 15.1$ (15. & .7) $19.4(24.6)$ & 1/23.1(29.1) 11 & $11.6(10.2)$ & $12.3(12.6)$ & $10.7(9.8)$ \\
\hline \multicolumn{10}{|c|}{ Interruption duration categories, m (\% ofl) } \\
\hline \multicolumn{3}{|c|}{0.7 days } & $35(52.2)$ & $26(41.9) / 44(42.7)$ & \multicolumn{2}{|c|}{$10(33.3) / 15(32.6)$} & $16(50.0)$ & & $20(50.0)$ \\
\hline \multicolumn{3}{|l|}{$\begin{array}{l}\text { 8-14 days } \\
15-21 \text { days }\end{array}$} & $14(20.9)$ & \multirow{2}{*}{$\begin{array}{l}15(24.2) / 26(25.2) \\
5(8.1) 6(5.8)\end{array}$} & \multicolumn{2}{|c|}{$10(33.3) / 16(34.8)$} & $7(21.9)$ & \multirow{2}{*}{$\begin{array}{l}8(33.3) \\
4(16.7)\end{array}$} & $10(25.0)$ \\
\hline \multirow{2}{*}{\multicolumn{3}{|c|}{ 22-28 days }} & $6(9.0)$ & & \multirow{2}{*}{\multicolumn{2}{|c|}{$\begin{array}{l}4(13.3) / 4(8.7) \\
0 / 1(2.2)\end{array}$}} & $5(15.6)$ & & $4(10.0)$ \\
\hline & & & $3(4.5)$ & $5(8.1) / 14(13.6)$ & & & $1(3.1)$ & $0(0.0)$ & $3(7.5)$ \\
\hline \multicolumn{3}{|c|}{$>28$ days } & $5(7.5)$ & \multirow[t]{2}{*}{$4(6.5) / 13(12.6)$} & $5(16.7)$ & 110(21.7) & $3(9.4)$ & $2(8.3)$ & $3(7.5)$ \\
\hline Reason for intemur & ions, $n(\%$ of $N)$ & & & & & & & & \\
\hline Adverse even & & & $44(9.0)$ & $46(9.4) 68(14.0)$ & $26(7.9)$ & 137(11.2) & $24(10.5)$ & $16(7.0)$ & $26(11.5)$ \\
\hline Abnormal lab & :sult & & $10(2.0)$ & $3(0.6) 6(1.2)$ & & 20 & $4(1.8)$ & $5(2.2)$ & $6(2.6)$ \\
\hline Investigator d & ision & & $3(0.6)$ & $2(0.4) / 2(0.4)$ & $2(0.6)$ & $1 / 3(0.9)$ & $2(0.9)$ & 0 & $2(0.9)$ \\
\hline $\begin{array}{l}\text { abbreviations: ADA } \\
\text { nenumber of patitsts } \\
\text { "interruptions are ba } \\
\text { resumption of study }\end{array}$ & 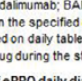 & 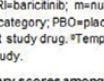 & $\begin{array}{l}\text { lumber of interruy } \\
\text { scebo. } \\
\text { peorary interrupt }\end{array}$ & uptions in the specift & fifed categony, $N$ & $\begin{array}{l}\text { Nenumber of } \\
\text { in holding of stu }\end{array}$ & atients in so & at is followed & \\
\hline Table 2. Summary & fePRO daily di & $\begin{array}{l}\text { ary scores among } \\
\text { Place }\end{array}$ & gatients retre & eated following stu & udyd & nuption: & Baricitinitiog & & \\
\hline & & $25(2$ & & & & & $54(52)^{\circ}$ & & \\
\hline Mean (SO) & $\begin{array}{l}\text { Study drug } \\
\text { initiation" }\end{array}$ & $\begin{array}{c}\text { Pre- } \\
\text { interruption' }\end{array}$ & $\begin{array}{l}\text { Last during } \\
\text { interruptione }\end{array}$ & $\begin{array}{c}\begin{array}{c}\text { Post- } \\
\text { interruption }\end{array} \\
\end{array}$ & $\begin{array}{l}\text { Studydrug } \\
\text { initiation }\end{array}$ & $\begin{array}{l}\text { Pre- } \\
\text { intervuption }\end{array}$ & $\begin{array}{ll}\text { Lasto } \\
\text { on' } \\
\text { intern }\end{array}$ & $\begin{array}{l}\text { during } \\
\text { ruption in }\end{array}$ & $\begin{array}{l}\text { Post- } \\
\text { interuptions }\end{array}$ \\
\hline MJS Duration & $\begin{array}{l}106 \\
(87)\end{array}$ & $\begin{array}{l}118 \\
(157)\end{array}$ & $\begin{array}{c}126 \\
(159)\end{array}$ & $\begin{array}{l}116 \\
(159)\end{array}$ & $\begin{array}{l}160 \\
(187)\end{array}$ & $\begin{array}{c}137 \\
(164)\end{array}$ & & 1.135 & $\begin{array}{l}121 \\
(188)\end{array}$ \\
\hline MJs Severity & $\begin{array}{l}5.5 \\
(2.1)\end{array}$ & $\begin{array}{l}4.3 \\
(2.0)\end{array}$ & $\begin{array}{c}4.5 \\
(2.0)\end{array}$ & $\begin{array}{c}4.2 \\
(1.9)\end{array}$ & $\begin{array}{c}5.8 \\
(2.0)\end{array}$ & $\begin{array}{l}4.2 \\
(2.2)\end{array}$ & & $\begin{array}{l}4.4 \\
2.22\end{array}$ & $\begin{array}{l}3.8 \\
(2.1)\end{array}$ \\
\hline Worst Joint Pain & $\begin{array}{l}5.8 \\
(1.7)\end{array}$ & $\begin{array}{l}4.6 \\
(2.0)\end{array}$ & $\begin{array}{l}4.9 \\
(2.0)\end{array}$ & $\begin{array}{l}4.4 \\
(1.9)\end{array}$ & $\begin{array}{l}6.1 \\
(2.0)\end{array}$ & $\begin{array}{l}4.6 \\
(2.2)\end{array}$ & & 2.7) & $\begin{array}{l}4.2 \\
(2.1)\end{array}$ \\
\hline Worst Tiredness & $\begin{array}{c}5.5 \\
(2.5)\end{array}$ & $\begin{array}{l}4.7 \\
(2.2)\end{array}$ & $\begin{array}{l}4.7 \\
(2.2)\end{array}$ & $\begin{array}{l}4.1 \\
(2.0)\end{array}$ & $\begin{array}{c}5.5 \\
(2.0)\end{array}$ & $\begin{array}{l}4.7 \\
(2.3)\end{array}$ & & $\begin{array}{l}4.9 \\
2.5)\end{array}$ & $\begin{array}{l}4.2 \\
(2.4)\end{array}$ \\
\hline
\end{tabular}

Asahi-kasei, YL Biologics, Sanofi, janssen, Eli Lilly and Company, GlaxoSmithKline, T. Cardillo Employee of: Eli Lilly and Company, D. Schlichting Employee of: Eli Lilly and Company, S. Beattie Employee of: Eli Lilly and Company, L. Chen Employee of: Eli Lilly and Company, T. Rooney Employee of: Eli Lilly and Company, J. Smolen: None declared

DOI: 10.1136/annrheumdis-2017-eular.1326

\section{FRI0125 RHEUMATOID ARTHRITIS PATIENTS WITH ANTI-ACETYLATED PEPTIDE ANTIBODIES STARTING THEIR FIRST TUMOR-NECROSE-FACTOR-INHIBITOR TREATMENT SHOW GREATER RESPONSE}

P. Studenic $^{1}$, S. Blüml ${ }^{1}$, H. Bang ${ }^{2}$, D. Sieghart ${ }^{1}$, D. Aletaha ${ }^{1}$, H. Haslacher ${ }^{3}$, T. Perkmann ${ }^{3}$, J.S. Smolen ${ }^{1,4}$, G. Steiner ${ }^{1} .{ }^{1}$ Internal Medicine 3, Division of Rheumatology, Medical University Vienna, Vienna, Austria; ${ }^{2}$ Orgentec Diagnostika, Mainz, Germany; ${ }^{3}$ Department of Laboratory Medicine, Medical University Vienna; ${ }^{4}$ Internal Medicine 2, Hietzing Hospital, Vienna, Austria

Background: Anti-acetylated-peptide antibodies (AAPA) have recently been described in rheumatoid arthritis (RA) patients.[1] Patients that show multiple autoantibody positivity have a higher likelihood to flare when stopping biological treatment. The role of AAPA antibodies for response to Tumor-Necrose-Factorinhibitor treatment (TNFi) has not been explored.

Objectives: To determine the prevalence and serological overlap of AAPA to rheumatoid factor (RF) and anti-citrullinated protein antibodies (ACPA) in a cohort of RA patients starting their TNF-inhibitor, and to assess their relation of autoantibody status to response to therapy.

Methods: We measured AAPA by ELISA using two acetylated peptides derived from vimentin, as well as RF and ACPA. We evaluated the prevalence of autoantibodies, baseline characteristics of autoantibody positive and negative patients, and their association with a $50 \%$ response by the Simplified disease activity index (SDAI50), and with achieving of SDAl low disease activity or remission at 6 months after starting the first TNFi. Likelihood ratios were calculated from logistic regression analyses. To better determine differences in SDAl change over time General Estimated Equation analyses (GEE) was used. Results: Among our 93 patients starting treatment on a TNFi ( $85 \%$ female, mean disease duration: $7.7 \pm 7$ years mean SDAI $20 \pm 13$ ), $50 \%$ were positive for AAPA, $57 \%$ for ACPA and $61 \%$ for RF (for overlap of antibodies see figure). There were no significant differences in baseline characteristics found between AAPA positive and negative patients. $61 \%$ of patients reached LDA or REM and $33 \%$ achieved an SDAl50 response after 6 months of TNFi treatment. AAPA positive patients showed a likelihood ratio $(\mathrm{LR}+)$ of $5.3(\mathrm{p}=0.022)$ to achieve an SDAI50 response and $3.9(p=0.048)$ to reach LDA/REM. In contrast, being RF or ACPA positive did not coincide with a higher likelihood of achieving SDAI50 ( $L R+$ of 0.08 ; $p=0.773$ and $1.09 ; p=0.297$, respectively) or LDA/REM ( $L R+$ of $1.83 ; p=0.177$ and $1.55 ; p=0.213$ ). Relative changes upon treatment with TNFi in composite scores were neither different between RF+ vs. RF- patients, nor between ACPA+ vs ACPA-patients; however AAPA+ showed significantly higher relative changes in SDAI $(p=0.021), \operatorname{CDAI}(p=0.025)$ and DAS $(p=0.022)$ compared to AAPA- patients. Of note, relative changes in CRP were similar between the groups.

GEE on up to 230 days of TNFi treatment or until change of treatment, showed no significant difference in SDAl courses comparing RF+ vs RF- or ACPA+ vs ACPA-

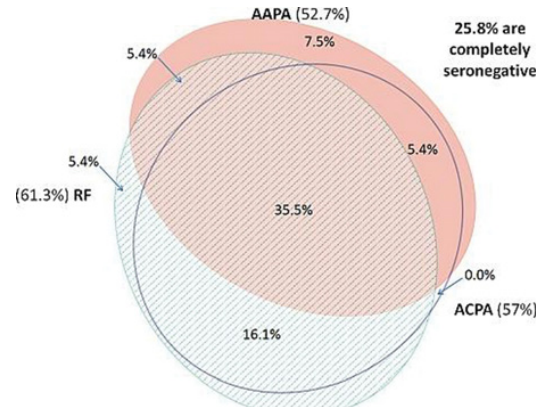

Figure 1. Overlap of RF, ACPA and AAPA positive patients.

patients; but for AAPA+ vs. AAPA- patients the difference in change in SDAI was significant $(p=0.045)$ over time.

Conclusions: AAPA positivity, in contrast to RF and ACPA positivity, appears to have a tighter association with greater levels of response in patients who are initiating TNFi-treatment. Therefore, AAPA might add additional information to estimate the chances of RA patients for responding to TNF-inhibitors.

References:

[1] Juarez M, Bang H, Hammar F, et al. Identification of novel antiacetylated vimentin antibodies in patients with early inflammatory arthritis. Ann Rheum Dis 2016;75(6):1099-107.

Disclosure of Interest: None declared

DOI: 10.1136/annrheumdis-2017-eular.5374

\section{FRI0126 AIMING FOR REMISSION ACCORDING TO ANY OF THE RHEUMATOID ARTHRITIS DISEASE ACTIVITY INDICES IS MORE IMPORTANT FOR PHYSICAL FUNCTION THAN THE ACTUAL CHOICE OF INDEX: A LONGITUDINAL ANALYSIS IN A CLINICAL PRACTICE SETTING (METEOR COHORT)}

${ }_{\text {P.D. Carvalho }}{ }^{1}$, R. Ferreira ${ }^{1}$, R. Landewé ${ }^{2}$, D. Vega-Morales ${ }^{3}$

K. Salomon-Escoto ${ }^{4}$, D.J. Veale ${ }^{5}$, J. da Silva ${ }^{1}$, P.M. Machado ${ }^{6} .{ }^{1} \mathrm{CHUC}$, Coimbra, Portugal; ${ }^{2}$ ARC, Amsterdam, Netherlands; ${ }^{3}$ HU/UANL, Monterrey, Mexico; ${ }^{4}$ UMass, Massachusetts, United States; ${ }^{5}$ DAMC, Dublin, Ireland; ${ }^{6}$ UCL, London, United Kingdom

Background: The association between remission and disability in patients with rheumatoid arthritis (RA) has been established mainly in clinical trial cohorts and not in "real-life" patients. Moreover, only a limited number of remission definitions have been tested.

Objectives: To compare the association between different remission criteria and physical function in patients with RA followed in clinical practice.

Methods: Longitudinal data from the METEOR database were used. Fifteen definitions of remission were tested: ACR-EULAR boolean-based; Simplified Disease Activity Index (SDAI); Clinical Disease Activity Index (CDAI); Disease Activity Score (DAS) and 28-joint count DAS (DAS28), both with ESR/CRP, with $3 / 4$ variables $(3 \mathrm{v} / 4 \mathrm{v})$, and various cut-offs tested. Disability was measured by the Health Assessment Questionnaire $(\mathrm{HAQ})$ and $\mathrm{HAQ} \leq 0.5$ was defined as a good outcome. Associations were investigated using generalised estimating equations (GEE), using $\mathrm{HAQ}<0.5$ as dependent variable and the various remission criteria as independent variables. Potential confounding factors (age, body mass index, gender, rheumatoid factor positivity, erosions and biologic treatment) were also tested. Sensitivity analyses were performed using first visits only and using patients with no missing data for all definitions of remission.

Results: Data from 32,915 patients and 157,899 visits were available. The most stringent definition of remission (table 1) was the ACR-EULAR boolean definition $(4.5 \%)$. The proportion of patients with $H A Q \leq 0.5$ among patients in remission

Table 1. Remission rates (\%) and association with $\mathrm{HAQ} \leq 0.5$

\begin{tabular}{|c|c|c|c|c|c|}
\hline \multirow{2}{*}{\multicolumn{2}{|c|}{ Remission definition }} & \multirow{2}{*}{$\begin{array}{c}\text { Remission } \\
\text { rate }\end{array}$} & \multicolumn{2}{|c|}{ HAQ $\leq 0.5(\%)$} & \multirow{2}{*}{$\begin{array}{c}\text { Adjusted OR } \\
\text { (95\%Cl) for } \\
\text { HAQ } 0.5 \text { (GEE) }\end{array}$} \\
\hline & & & $\begin{array}{l}\text { Among patients } \\
\text { in remission }\end{array}$ & $\begin{array}{l}\text { Among patients } \\
\text { in non-remission }\end{array}$ & \\
\hline \multicolumn{2}{|c|}{ ACR-EULAR boolean } & 4.5 & 87.0 & 34.1 & $2.6(2.3-2.9)$ \\
\hline \multicolumn{2}{|c|}{ CDAI $\leq 2.8$} & 13.4 & 78.5 & 27.4 & $3.2(2.9-3.5)$ \\
\hline \multicolumn{2}{|l|}{ SDAI $\leq 3.3$} & 17.1 & 78.1 & 25.7 & $3.4(3.0-3.7)$ \\
\hline \multirow[t]{2}{*}{ DAS-CRP $<1.6$} & $4 \mathrm{v}$ & 38.6 & 59.1 & 19.3 & $3.2(2.9-3.5)$ \\
\hline & $3 \mathrm{v}$ & 39.1 & 56.4 & 20.7 & $2.8(2.6-3.0)$ \\
\hline \multirow[t]{2}{*}{ DAS-ESR $<1.6$} & $4 \mathrm{v}$ & 31.7 & 63.2 & 22.6 & $3.0(2.7-3.2)$ \\
\hline & $3 \mathrm{v}$ & 30.4 & 60.4 & 24.3 & $2.6(2.4-2.8)$ \\
\hline \multirow[t]{2}{*}{ DAS28-CRP $<2.6$} & $4 \mathrm{v}$ & 34.8 & 62.8 & 20.2 & $3.3(3.0-3.6)$ \\
\hline & $3 v$ & 37.5 & 57.7 & 21.3 & $2.8(2.6-3.0)$ \\
\hline \multirow[t]{2}{*}{ DAS28-ESR $<2.6$} & $4 \mathrm{v}$ & 25.2 & 68.1 & 26.5 & $2.8(2.6-3.1)$ \\
\hline & $3 v$ & 24.4 & 62.5 & 28.7 & $2.3(2.2-2.5)$ \\
\hline \multirow[t]{2}{*}{ DAS28-CRP $\leq 1.9^{*}$} & $4 \mathrm{v}$ & 20.0 & 72.8 & 26.1 & $2.9(2.7-3.2)$ \\
\hline & $3 v$ & 21.7 & 64.5 & 27.4 & $2.3(2.2-2.5)$ \\
\hline \multirow[t]{2}{*}{ DAS28-ESR $\leq 22^{*}$} & $4 \mathrm{~V}$ & 18.4 & 71.3 & 29.9 & $2.6(2.4-2.8)$ \\
\hline & $3 v$ & 17.3 & 64.4 & 31.8 & $2.1(1.9-2.2)$ \\
\hline
\end{tabular}

